\title{
Aerated chicken, cow, and turkey manure extracts differentially affect lettuce and kale yield in hydroponics
}

\author{
Peter Tikasz $^{1}$ (D) $\cdot$ Sarah MacPherson ${ }^{1} \cdot$ Viacheslav Adamchuk $^{1} \cdot$ Mark Lefsrud $^{1}$
}

Received: 19 September 2018 / Accepted: 8 April 2019 / Published online: 22 April 2019

(c) The Author(s) 2019

\begin{abstract}
Purpose Manure extracts possess great potential as alternate inorganic fertilizers. However, limited information exists on how manure influences plant growth. This study's aim was to determine the impact of aerated manure extracts on romaine lettuce (Lactuca sativa var. longifolia) and Russian kale (Brassica napus var. 'Red Russian') in hydroponic systems.

Methods Chicken, cow, and turkey manure extract solutions (10, 25, and $50 \mathrm{~g} / \mathrm{L}$ manure) were compared to a control (Hoagland) solution for lettuce and kale grown in an ebb and flow hydroponic system.

Results The aboveground dry mass of lettuce grown in a $50 \mathrm{~g} / \mathrm{L}$ turkey manure extract solution was greater than that of the control. The largest aboveground wet mass for kale occurred with the control. Nutrient analyses of all manure extract solutions showed a $29 \%-79 \%$ higher concentration of $\mathrm{NH}_{4}-\mathrm{N}$ and higher total nitrogen than the control. Principal component analysis of the nutrient solutions identified six nutrients that should be monitored to maximize plant yield when using manure extracts in hydroponics: $\mathrm{NO}_{3}{ }^{-}, \mathrm{NH}_{4}{ }^{+}, \mathrm{Ca}, \mathrm{Mg}, \mathrm{Mn}$, and $\mathrm{Na}$.

Conclusions Healthy lettuce and kale plants were grown in turkey manure extract solution $(50 \mathrm{~g} / \mathrm{L})$. However, reduced aboveground wet and dry mass were recorded for both plants in chicken and cow manure extract solutions compared to the control. $\mathrm{NH}_{4}{ }^{+}$toxicity likely killed all plants grown in chicken extract $(50 \mathrm{~g} / \mathrm{L})$. Apart from $\mathrm{NH}_{4}{ }^{+}$and $\mathrm{P}$, all nutrients were below suggested concentrations suggested for lettuce growth. A combined manure/mineral fertilizer may be necessary to optimize hydroponic solutions.
\end{abstract}

Keywords Brassica napus $\cdot$ Composting $\cdot$ Hydroponics $\cdot$ Lactuca sativa $\cdot$ Manure

\section{Introduction}

Hydroponic plant production is a soilless agricultural practice that comprises a nutrient solution and an artificial rooting substrate to support plant growth (Kumar and Cho 2014). Hydroponic systems are mostly employed in greenhouses, where the environment can be controlled and plant production can occur year round (Lee and Lee 2015). Under these conditions, pest control problems, pesticide use, and weed growth are considerably reduced (Surendran et al. 2016;

Electronic supplementary material The online version of this article (https://doi.org/10.1007/s40093-019-0261-y) contains supplementary material, which is available to authorized users.

Peter Tikasz

peter.tikasz@mail.mcgill.ca

1 Department of Bioresource Engineering, McGill University, 21,111 Lakeshore Road, Sainte-Anne-de-Bellevue, QC, Canada
Tomasi et al. 2015). In addition, hydroponic systems often use less water and have higher water efficiency, as nutrient solutions are not lost to ground infiltration (Surendran et al. 2016). As such, the productivity per unit area of a hydroponic system is higher than that of field-grown agriculture, and growing crops in controlled environments allow for the cultivation of plants with higher and more uniform nutritional values (Surendran et al. 2016; Suvo et al. 2017).

As organic soil is not required in hydroponic systems, conventional issues such as inadequate soil fertility, soil erosion, and compaction are absent. The use of organic fertilizers in hydroponics systems, however, remains a challenge as achieving plant yields comparable to those grown with inorganic fertilizers is more difficult, balancing nutrient solutions is problematic, and the $\mathrm{pH}$ and electrical conductivity (EC) of solutions fluctuate considerably (Williams and Nelson 2014). In recent years, alternate hydroponic substrates derived from solid municipal waste have been considered (Haghighi et al. 2016). In organic farming, "compost teas" 
have been investigated as a replacement or supplemental fertilizer (Carballo et al. 2009). Compost teas are watery extracts prepared with compost or compost mixed with manure, to cultivate beneficial microorganisms. Nutrients found in compost teas originate from the compost, or they may be added from external sources (Hargreaves et al. 2009; Ingham and Millner 2006). They are sprayed on agricultural soils and plants, reportedly stimulating root and vegetative growth while increasing soil microbial activity (Haghighi et al. 2016; Haller et al. 2016; Pane et al. 2016). The remedial characteristics of compost teas have garnered increasing interest, as they promote antifungal activity and reduce the severity of several plant pathogen diseases including early blight (Alternaria solani) and grey mould (Botrytis cinereal) (Nartey et al. 2017; On et al. 2015; Welke 2005).

Compost teas may be aerated or non-aerated. Aerated compost teas are compost extracts that are brewed with biological and non-biological materials such as molasses, kelp, rock dust, and humic-fulvic acids to maximize microbial growth (Ingham 2000). They are brewed in an aerobic environment for an 18-h-36-h period that may be further extended (Scheuerell and Mahaffee 2002). Non-aerated compost teas are produced by steeping compost in water for several days to weeks (Ingham and Millner 2006). For both aerated and non-aerated compost teas, fermentation parameters can influence the composition and population of microbial species (Scheuerell and Mahaffee 2002).

In Canada, lettuce and kale were amongst the top five vegetable imports in 2016, representing CAD \$447 million and CAD $\$ 374$ million in annual sales, respectively (Agriculture and Agri-Food Canada 2017). During the same period, lettuce grown in Canada generated CAD \$112 million in revenue. To meet the growing demands of the Canadian vegetable market, new methods must be developed to increase production and decrease cost. Animal manure has been suggested as a nutrient source, as it is inexpensive and readily available (Agriculture and Agri-Food Canada 2017).

The benefits of using compost teas prepared with sheep, beef, chicken, and cow manure, municipal solid waste, or vermicompost in soil-based crop production systems have been extensively reported (AboSedera et al. 2015; Abul-Soud et al. 2016; Duffy et al. 2004; Fritz et al. 2012; Hargreaves et al. 2009; Jack and Nelson 2010; Radin and Warman 2011; Zhai 2009). Animal manure has high cation exchange capacity and contains all the required plant nutrients that can prevent micronutrient deficiency in crops (Nelson 2011). Nevertheless, the use of animal manure requires monitoring of ammonium, sodium, and iron levels, as well as overall nutrient solution content to control toxicity (Garraway 1982).

Investigations examining the effectiveness of animal manure on plant growth in hydroponic systems to date have reported differing results (Garland et al. 1999; Garraway
1982; Ingham 2002; Leudtke 2010). For instance, it has been reported that chicken manure-based vermicompost tea containing $\mathrm{N}$-indole-3-acetic acid, cytokine, gibberellins, and humic acid promotes tomato and lettuce seed germination and seedling growth (Arancon et al. 2012). Contrarily, another study concluded that the use of the nutrient film technique with chicken manure was inferior to a control hydroponic solution with respect to lettuce plant biomass yield (El-Shinawy et al. 1999). Together, the previous study caveats include a lack of uniformity, insufficient monitoring, and an absence of appropriate controls when applying manure extract preparations to seeds and plants in hydroponics.

The objective of this study was to determine the impact of aerated manure-based extracts on lettuce and kale growth and yield in hydroponic systems using three manure sources (chicken, cow, and turkey) and different concentrations $(10 \mathrm{~g} / \mathrm{L}, 25 \mathrm{~g} / \mathrm{L}$, and $50 \mathrm{~g} / \mathrm{L})$. Data support the continued monitoring of several key nutrients in manure extracts to avoid toxicity while demonstrating that different manure sources and manure extract solution concentrations differentially impact plant yield when grown hydroponically. Further to this, these data fill critical knowledge gaps when considering the future use of manure-derived or supplemented manure-derived solutions in hydroponic systems.

\section{Materials and methods}

\section{Germination and plant growth}

Red Russian kale (Brassica napus var. 'Red Russian') (S8422-001, Richters, Goodwood, ON, Canada) and romaine lettuce (Lactuca sativa var. longifolia) (Ridgeline Pelleted MT0 OG, Johnny's, Winslow ME, US) seeds were germinated in pre-washed rockwool rooting medium cubes with $\mathrm{dH}_{2} \mathrm{O}$ (Grodan, Roermond, Netherlands). For each plant species, 12 cubes were seeded (two seeds per cube) in a growing tray and transferred into a growth chamber (CMP4030, Conviron, Inc., Winnipeg, MB, Canada) for 2 weeks with a constant temperature of $25{ }^{\circ} \mathrm{C}, 50 \%$ relative humidity, and a 16-h photoperiod. Deionized water was added when necessary to maintain water levels. One week after germination, seedlings were thinned to one seedling per rockwool cube and grown for one more week in the growth chamber. A total of 12 kale and 12 lettuce seedlings were then placed in $10-\mathrm{cm}$ rockwool cubes and transferred to an ebb and flow hydroponic system in the greenhouse. The seedlings were equally distributed and randomly placed within six hydroponic beds to minimize edge effect (Fig. 1).

All plants were harvested and dried 28 days after being transferred to the greenhouse (42 days total). At harvest, the following characteristics were measured: aboveground 


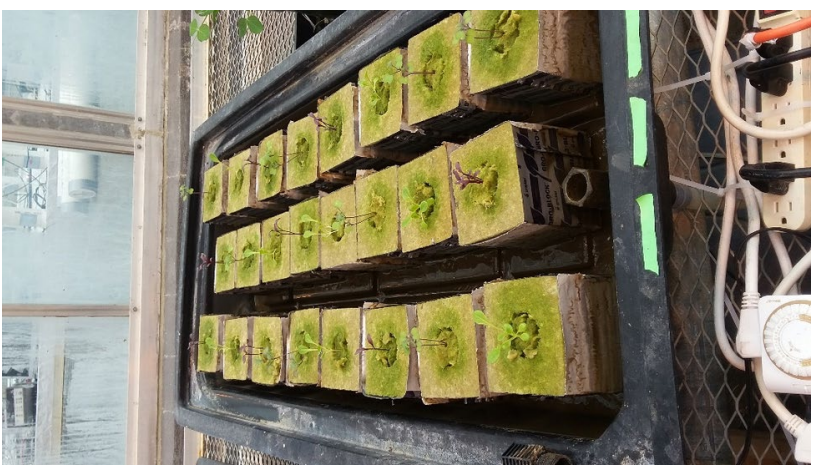

Fig. 1 Placement of 24 rockwool cubes with kale and lettuce seedlings after transfer to an ebb and flow hydroponic system

wet mass and the number of mature leaves ( $\geq 2 \mathrm{~cm}$ in diameter). Plant samples were oven-dried at $40{ }^{\circ} \mathrm{C}$ for 5 days and dry mass was measured with a scale (APX-150, Denver Instruments, Bohemia, NY, US). Dried samples were ground (CBG100SC, Black \& Decker, Towson, MD, US) and stored in plastic containers until plant tissue nutrient analyses were performed.

\section{Preparation of manure-derived hydroponic nutrient solutions}

Cow and chicken manure were sourced from McGill University's Macdonald Campus Farm in Sainte-Anne-de-Bellevue, QC, Canada. Turkey manure was sourced from Aviculture KDEM, Inc. (Saint-Gabriel-de-Valcartier, QC, Canada), where it was left outside and exposed to the external environment for 1-6 months prior to use. For each manure type, three aerated manure extract solutions were prepared with different concentrations as described previously (Luedtke 2010 and El-Shinawy et al. 1999). In brief, $20 \mathrm{~g}, 50 \mathrm{~g}$, and $100 \mathrm{~g}$ manure were separately diluted in $30 \mathrm{~L}$ tap water. Solutions were aerated with an air pump for $48 \mathrm{~h}$ then filtered through a 1-mm sieve to remove large fragments. Next, the solutions were diluted with tap water to reach a final volume of $60 \mathrm{~L}$ with concentrations of $10 \mathrm{~g} / \mathrm{L}, 25 \mathrm{~g} / \mathrm{L}$, and $50 \mathrm{~g} / \mathrm{L}$. Solutions were replaced every 14 days with freshly prepared solutions.

Identical ebb and flow (recirculating) hydroponic systems were set up for each experimental solution, including the control Hoagland solution. Each bed was flooded for $15 \mathrm{~min}$ every hour, resulting in a water depth of no more than $5 \mathrm{~cm}$ per bed. One bed contained modified full-strength Hoagland solution (Hoagland and Arnon 1950) as a control. The other beds contained the chicken, cow, and turkey manure extract solutions at three different concentrations $(10 \mathrm{~g} / \mathrm{L}, 25 \mathrm{~g} / \mathrm{L}$, and $50 \mathrm{~g} / \mathrm{L}$ ). Three replicas per plant (lettuce and kale) were grown for each manure source and each concentration.

\section{Electrical conductivity and $\mathrm{pH}$ of manure-derived hydroponic nutrient solutions}

$\mathrm{EC}$ and $\mathrm{pH}$ of each manure extract solution were measured every 2 days during the growth period in the greenhouse with a handheld EC meter (Hanna EC/TDS meter, Woonsocket, RI, US) and an AB15 pH meter (Fisher Scientific, Waltham, MA, US).

\section{Manure-derived hydroponic nutrient solution analyses}

Three $50 \mathrm{~mL}$ samples of each manure extract solution were taken on a weekly basis. Samples were filtered with a Whatman qualitative filter paper No 1 (GE Healthcare Life Sciences, United Kingdom), and stored in a freezer at $-78{ }^{\circ} \mathrm{C}$ prior to analysis.

The ammonium concentration of each manure extract solution was determined using the Quickchem ${ }^{\circledR}$ method for ammonium, as per the manufacturer's instructions (Lachat Instruments, Milwaukee, WI, US). Briefly, equal amounts of buffer solution and sample were mixed. The buffer solution contained phosphate, salicylate, and hypochlorite. The chemical reaction was amplified by heating the solution to $60{ }^{\circ} \mathrm{C}$. Ammonium was quantified by measuring the resulting green colour at $660 \mathrm{~nm}$ with a flow injection autoanalyzer, according to the manufacturer's instructions (Lachat Instruments 2008a).

The Quickchem method (Lachat Instruments 2008a) was also used to determine the nitrate concentration of each solution. A total of $5 \mathrm{~mL}$ each sample was passed through a copperized cadmium column $(\mathrm{Cu}-\mathrm{Cd}$ column $)$ that reduced nitrates into nitrites (Otsuki 1978). When combined with a sulfanilamide and phosphoric acid reagent, nitrites turned magenta and this colour was quantified at $520 \mathrm{~nm}$ with a flow injection analyser, according to the manufacturer's instructions (Lachat Instruments 2008a).

To determine the total nitrogen content in leaf tissues, $0.16 \mathrm{~g}$ of ground dry sample was digested with an equivalent volume of extraction solution in an autoclave for $30 \mathrm{~min}$ at $120^{\circ} \mathrm{C}$. Next, an alkaline persulfate solution was added and nitrogen was quantified as described previously (Ebina et al. 1983). Total $P$ was measured using the QuickChem ${ }^{\circledR}$ method for phosphorus according to the manufacturer's instructions (Lachat Instruments 2008b). Following digestion with ammonium molybdate in an ascorbic-reducing solution, the concentration of phosphorus was determined with a flow injection analyzer at $880 \mathrm{~nm}$ as described previously (Cabrera and Beare 1993) and according to the manufacturer's instructions (Lachat Instruments 2008b). 


\section{Elemental analyses}

Concentrations of several elements ( $\mathrm{K}, \mathrm{Mg}, \mathrm{Na}, \mathrm{Ca}, \mathrm{Mn}$, $\mathrm{Fe}, \mathrm{Cu}$, and $\mathrm{Zn}$ ) were determined as described previously (Zarcinas et al. 1987). Briefly, each manure extract solution was diluted 20-fold with $\mathrm{ddH}_{2} \mathrm{O}$ prior to analysis. For leaf tissue analysis, $0.16 \mathrm{~g}$ dried leaf tissue from each plant was incubated overnight with $10 \mathrm{~mL}$ nitric acid. The following day, samples were heated for $4 \mathrm{~h}$ at $120^{\circ} \mathrm{C}$, then transferred and diluted with $\mathrm{ddH}_{2} \mathrm{O}$ in a $50 \mathrm{~mL}$ Falcon tube. The samples were analyzed with the Varian 820-MS ICP Mass Spectrometer (Analytik Jena, Jena, Germany).

\section{Statistical analysis}

Principal component analysis (PCA) with JMP version 13.0.0 software was used to determine the effect of nutrients in the manure extract solutions on plant wet and dry mass. Analysis of variance (ANOVA) was conducted to determine differences among manure extract solutions. Posthoc comparisons were accomplished using Tukey's honest significance test (HSD). A significance level of $\alpha<0.05$ was employed for all statistical tests. Statistical analyses were run separately for kale and lettuce. Mean values were calculated for nutrients and biomass. JMP version 13.0.0 software was used to construct all graphs.

\section{Results and discussion}

\section{Plant yield}

Lettuce grown in turkey manure extract $(50 \mathrm{~g} / \mathrm{L})$ solution yielded the greatest aboveground wet mass average $(19.1 \pm 2.7 \mathrm{~g})$, followed by lettuce grown in the control (Hoagland) solution $(17.5 \pm 0.7$ g) (Fig. 2). Kale grown in Hoagland solution yielded the greatest aboveground wet mass average $(11.9 \pm 0.5 \mathrm{~g})$, followed by kale grown in the turkey manure extract $(50 \mathrm{~g} / \mathrm{L})$ solution $(6.1 \pm 1.0 \mathrm{~g})$. For lettuce, the highest aboveground dry mass was recorded when grown in turkey manure extract $(50 \mathrm{~g} / \mathrm{L})$ solution $(1.4 \pm 0.2 \mathrm{~g})$, followed by lettuce grown in Hoagland solution $(0.9 \pm 0.0 \mathrm{~g} ; \alpha<0.05)$. For kale, the highest aboveground dry mass was measured in the Hoagland solution $(0.8 \pm 0.0 \mathrm{~g})$ followed by kale grown with the turkey manure extract $(50 \mathrm{~g} / \mathrm{L})$ solution $(0.6 \pm 0.1 \mathrm{~g}$; Fig. 3$)$.

When examining how chicken manure affected plant yield, data indicated that the higher the chicken manure concentration, the more detrimental effect it had on plants. More specifically, all plants died when grown in the chicken manure extract $(50 \mathrm{~g} / \mathrm{L})$ solution. For cow manure extract solutions, increases in aboveground wet mass were observed for kale $(1.1 \pm 0.0-3.4 \pm 0.4 \mathrm{~g})$ and
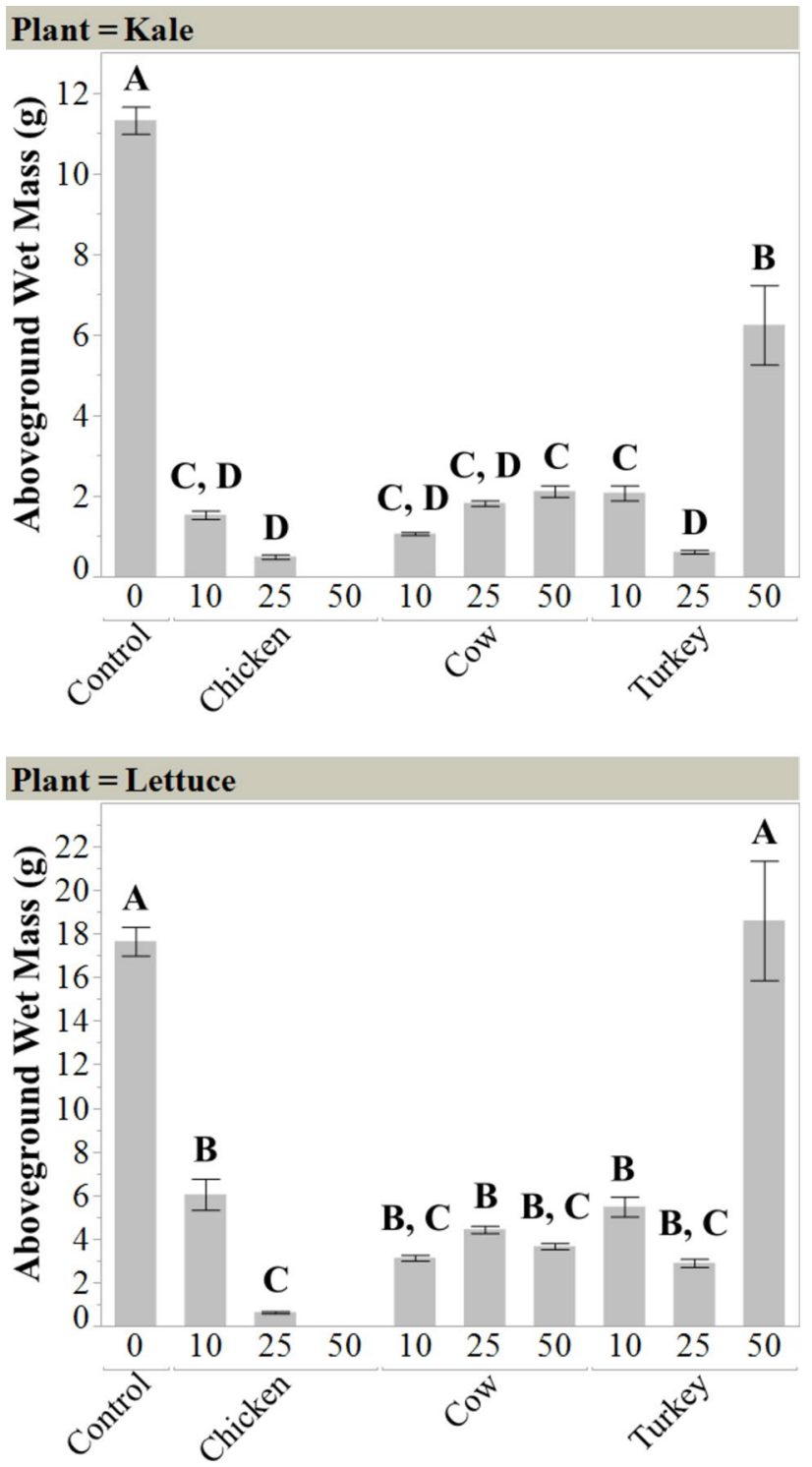

Fig. 2 Mean aboveground wet mass values for manure extract nutrient solutions ( \pm standard error), using Hoagland solution as the control. Letters above the columns show HSD statistical significance $(\alpha<0.05)$. Mean values for plants grown in the $50 \mathrm{~g} / \mathrm{L}$ chicken manure extract solution were not included in this analysis, as none were viable at this concentration

lettuce $(3.1 \pm 0.1-6.6 \pm 1.0 \mathrm{~g})$, as the manure concentration increased from $10 \mathrm{~g} / \mathrm{L}$ to $50 \mathrm{~g} / \mathrm{L}$. For turkey manure extract solutions, an increase in yield was observed as the manure concentration increased from $10 \mathrm{~g} / \mathrm{L}$ to $50 \mathrm{~g} / \mathrm{L}$; however, the lowest plant yield was recorded for plants grown in turkey manure extract $(25 \mathrm{~g} / \mathrm{L})$ solution. It is possible that the microbial and nutrient composition of the turkey manure was affected when it was exposed to the outside environment for 1-6 months prior to collection (Shinohara et al. 2011). Importantly, plants grown in the turkey manure extract $(50 \mathrm{~g} / \mathrm{L})$ solution exhibited a significantly higher yield with 

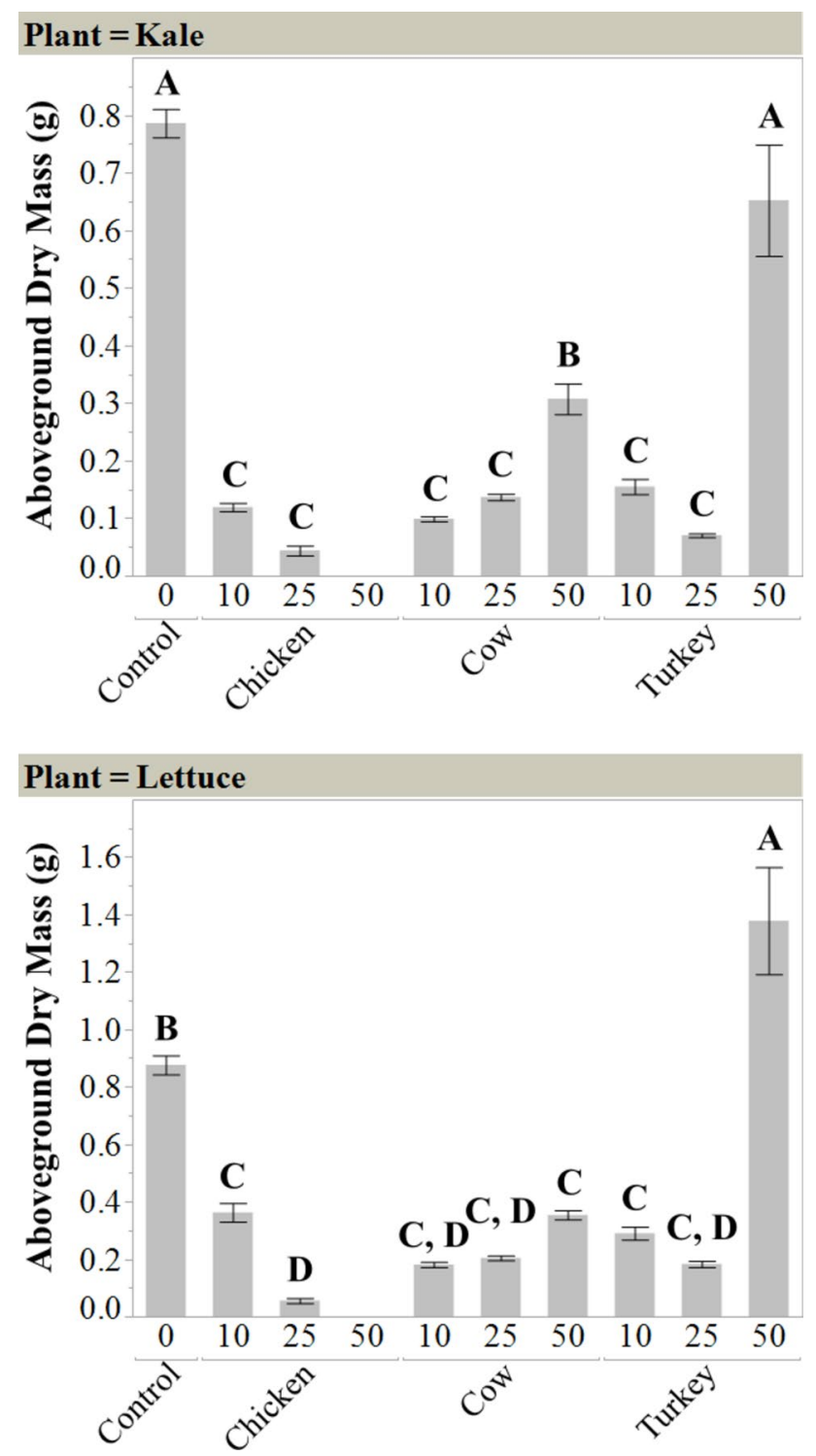

Fig. 3 Mean aboveground dry mass for kale and lettuce grown in different manure extract solutions ( \pm standard error), using Hoagland solution as the control. Letters above the columns indicate HSD statistical significance $(\alpha<0.05)$. Mean values for plants grown in the $50 \mathrm{~g} / \mathrm{L}$ chicken manure extract solution were not included in this analysis, as none were viable at this concentration

greater $\mathrm{NO}_{3}, \mathrm{Mg}$, and $\mathrm{Mn}$ content than plants grown in either chicken or cow manure extract solutions $(\alpha<0.05)$ (Table 1$)$. Further increases in manure concentration, above $50 \mathrm{~g} / \mathrm{L}$, should be considered for turkey and cow manure to identify a growth threshold for both plant species, as was observed for plants grown in chicken manure-derived solutions at $50 \mathrm{~g} / \mathrm{L}$.

To determine the effect of different manure extract solutions on leaf production, total mean numbers of leaves for both lettuce and kale in all nutrient solutions were compared (Fig. 4). The highest mean number of leaves was recorded for lettuce grown in turkey manure extract $(50 \mathrm{~g} / \mathrm{L})$ solution (10.5 \pm 0.4 leaves), followed by Hoagland solution $(7.3 \pm 0.1$ leaves). For kale, the highest mean number of leaves was counted for plants grown in Hoagland solution (7.3 \pm 0.1 leaves $)$, followed by the turkey manure extract $(50 \mathrm{~g} / \mathrm{L})$ solution $(6.5 \pm 0.2$ leaves $)$.

It has been suggested that the optimal $\mathrm{pH}$ for hydroponic solutions ranges between 5.6 and 6.5 (Food and Agricultural Organization of the United Nations [FAO] 2013). In comparison, the manure extract solutions used in this study ranged between 7.8 and 8.2, while EC values ranged between 0.55 and $1.62 \mathrm{mS} / \mathrm{cm}$ (HI 98312, Hanna Instruments, Woonsocket, Rhode Island, US) (Table 2 and Fig. 5). It should further be noted that the $\mathrm{pH}$ of the control Hoagland solution in this study was approximately 7.5, and the EC was $2.1 \mathrm{mS} /$ $\mathrm{cm}$ over for the duration of the experiment.

\section{Nutrient variation between chicken, cow, and turkey manure extract solutions}

PCA identified six key nutrients to monitor in the aerated manure extract solutions that could predict plant yield. For both lettuce and kale plants, there were two clusters: (1) $\mathrm{NO}_{3}, \mathrm{Ca}, \mathrm{Mg}$, and $\mathrm{Mn}$ and (2) $\mathrm{NH}_{4}$ and $\mathrm{Na}$, as identified in Fig. 6a, b. The first four nutrients $\left(\mathrm{NO}_{3}, \mathrm{Ca}, \mathrm{Mg}\right.$, and $\mathrm{Mn}$ ) were positively correlated with aboveground wet and dry mass, while a negative correlation was identified for $\mathrm{NH}_{4}$ and $\mathrm{Na}$.

The control Hoagland solution contained the highest $\mathrm{NO}_{3}$ concentration, followed by the turkey manure extract $(50 \mathrm{~g} / \mathrm{L})$ solution, with $676.9 \pm 93.9 \mathrm{mg} / \mathrm{L}$ and $52.0 \pm 24.5 \mathrm{mg} / \mathrm{L}$, respectively (Table 1 ). For chicken manure extract solutions, the $\mathrm{NH}_{4}$ concentration increased as manure concentrations increased, with a maximum of $366.6 \pm 28.9 \mathrm{mg} / \mathrm{L}$ at $50 \mathrm{~g} / \mathrm{L}$ chicken manure. For all cow manure extract solutions, $\mathrm{NH}_{4}$ concentrations remained low and stable at approximately $16 \mathrm{mg} / \mathrm{L}$. For turkey manure extract solutions, $\mathrm{NH}_{4}$ concentrations fluctuated, peaking at $164.2 \pm 14.8 \mathrm{mg} / \mathrm{L}$ in the $25 \mathrm{~g} / \mathrm{L}$ solution.

The presence of sodium in the manure extract solutions was significantly higher ( $>40 \mathrm{mg} / \mathrm{L})$, in the chicken manure extract $(50 \mathrm{~g} / \mathrm{L})$ and turkey manure $(25 \mathrm{~g} / \mathrm{L})$ extract solutions. The lowest concentration was measured in the control Hoagland solution, at $9.4 \pm 0.7 \mathrm{mg} / \mathrm{L}$. Calcium and magnesium exhibited similar trends, where an increase in manure concentration increased both nutrients' concentrations (Table 1). The highest concentration of calcium was recorded in the control Hoagland solution at $159.0 \pm 13.6 \mathrm{mg} / \mathrm{L}$. The highest concentration of magnesium was measured in the cow manure extract $(50 \mathrm{~g} / \mathrm{L})$ solution at $45.4 \pm 3.0 \mathrm{mg} / \mathrm{L}$, but it was not significantly different from the control $(39.1 \pm 2.9 \mathrm{mg} / \mathrm{L})$. Manganese concentrations fluctuated between and within different manure 
Table 1 Nutrient variation in the manure extract solutions

\begin{tabular}{|c|c|c|c|c|c|c|c|c|c|c|c|c|c|}
\hline \multirow[b]{2}{*}{ Treatment } & \multirow[b]{2}{*}{$\begin{array}{l}\text { Concen- } \\
\text { tration }\end{array}$} & \multicolumn{2}{|l|}{$\mathrm{NO}_{3}$} & \multicolumn{2}{|l|}{$\mathrm{NH}_{4}$} & \multicolumn{2}{|l|}{$\mathrm{Na}$} & \multicolumn{2}{|l|}{$\mathrm{Ca}$} & \multicolumn{2}{|l|}{$\mathrm{Mg}$} & \multicolumn{2}{|l|}{$\mathrm{Mn}$} \\
\hline & & $\mathrm{mg} / \mathrm{L}$ & S.E. & $\mathrm{mg} / \mathrm{L}$ & S.E. & $\mathrm{mg} / \mathrm{L}$ & S.E. & $\mathrm{mg} / \mathrm{L}$ & S.E. & $\mathrm{mg} / \mathrm{L}$ & S.E. & $\mu \mathrm{g} / \mathrm{L}$ & S.E. \\
\hline Control & $60 \mathrm{~L}$ & $676.9^{\mathrm{A}}$ & 93.9 & $0.7^{\mathrm{D}}$ & 0.1 & $9.4^{\mathrm{E}}$ & 0.7 & $159.0^{\mathrm{A}}$ & 13.6 & $39.1^{\mathrm{A}, \mathrm{B}}$ & 2.9 & $399.7^{\mathrm{A}}$ & 15.9 \\
\hline \multirow[t]{3}{*}{ Chicken } & $10 \mathrm{~g} / \mathrm{L}$ & $0.5^{\mathrm{B}}$ & 0.4 & $100.1^{\mathrm{C}, \mathrm{D}}$ & 14.5 & $12.1^{\mathrm{E}}$ & 0.7 & $16.7^{\mathrm{D}, \mathrm{E}}$ & 1.3 & $5.9^{\mathrm{E}, \mathrm{F}}$ & 0.9 & $112.0^{\mathrm{B}}$ & 27.6 \\
\hline & $25 \mathrm{~g} / \mathrm{L}$ & $2.0^{\mathrm{B}}$ & 1.1 & $221.9^{\mathrm{B}}$ & 11.0 & $30.6^{\mathrm{B}, \mathrm{C}, \mathrm{D}}$ & 6.2 & $21.0^{\mathrm{D}, \mathrm{E}}$ & 0.4 & $13.4^{\mathrm{D}, \mathrm{E}, \mathrm{F}}$ & 1.6 & $217.5^{\mathrm{A}, \mathrm{B}}$ & 68.6 \\
\hline & $50 \mathrm{~g} / \mathrm{L}$ & $2.7^{\mathrm{B}}$ & 0.9 & $366.6^{\mathrm{A}}$ & 28.9 & $50.2^{\mathrm{A}}$ & 2.4 & $44.0^{\mathrm{C}}$ & 0.6 & $20.6^{\mathrm{C}, \mathrm{D}}$ & 1.6 & $91.9^{\mathrm{B}}$ & 19.9 \\
\hline \multirow[t]{3}{*}{ Cow } & $10 \mathrm{~g} / \mathrm{L}$ & $1.5^{\mathrm{B}}$ & 0.8 & $17.9^{\mathrm{D}}$ & 0.9 & $12.5^{\mathrm{D}, \mathrm{E}}$ & 0.5 & $34.0^{\mathrm{C}, \mathrm{D}}$ & 1.8 & $10.6^{\mathrm{D}, \mathrm{E}, \mathrm{F}}$ & 0.9 & $105.5^{\mathrm{B}}$ & 12.2 \\
\hline & $25 \mathrm{~g} / \mathrm{L}$ & $3.6^{\mathrm{B}}$ & 2.7 & $16.6^{\mathrm{D}}$ & 2.1 & $14.4^{\mathrm{C}, \mathrm{D}, \mathrm{E}}$ & 1.2 & $50.7^{\mathrm{B}, \mathrm{C}}$ & 4.4 & $20.6^{\mathrm{C}, \mathrm{D}, \mathrm{E}}$ & 0.7 & $196.5^{\mathrm{A}, \mathrm{B}}$ & 42.1 \\
\hline & $50 \mathrm{~g} / \mathrm{L}$ & $15.7^{\mathrm{B}}$ & 5.0 & $15.4^{\mathrm{D}}$ & 3.7 & $29.6^{\mathrm{B}, \mathrm{C}}$ & 4.4 & $62.4^{\mathrm{B}}$ & 1.8 & $45.4^{\mathrm{A}}$ & 3.0 & $176.2^{\mathrm{B}}$ & 15.7 \\
\hline \multirow[t]{3}{*}{ Turkey } & $10 \mathrm{~g} / \mathrm{L}$ & $8.0^{\mathrm{B}}$ & 4.0 & $37.1^{\mathrm{D}}$ & 12.4 & $19.3^{\mathrm{C}, \mathrm{D}, \mathrm{E}}$ & 0.8 & $10.4^{\mathrm{E}}$ & 1.3 & $4.0^{\mathrm{F}}$ & 0.4 & $41.0^{\mathrm{B}}$ & 8.4 \\
\hline & $25 \mathrm{~g} / \mathrm{L}$ & $1.9^{\mathrm{B}}$ & 0.6 & $164.2^{\mathrm{B}, \mathrm{C}}$ & 14.8 & $42.2^{\mathrm{A}, \mathrm{B}}$ & 4.0 & $13.8^{\mathrm{E}}$ & 1.6 & $3.5^{\mathrm{F}}$ & 0.2 & $95.7^{\mathrm{B}}$ & 7.2 \\
\hline & $50 \mathrm{~g} / \mathrm{L}$ & $52.0^{\mathrm{B}}$ & 24.5 & $45.4^{\mathrm{D}}$ & 14.1 & $29.3^{\mathrm{B}, \mathrm{C}}$ & 1.8 & $23.2^{\mathrm{D}, \mathrm{E}}$ & 1.5 & $29.1^{\mathrm{B}, \mathrm{C}}$ & 3.7 & $380.3^{\mathrm{A}}$ & 65.1 \\
\hline
\end{tabular}

Mean nutrient concentrations in the chicken, cow, and turkey manure extract solutions ( \pm standard error [S.E.]) for nitrate $\left(\mathrm{NO}_{3}\right)$, ammonium $\left(\mathrm{NH}_{4}\right)$, sodium $(\mathrm{Na})$, calcium $(\mathrm{Ca})$, magnesium $(\mathrm{Mg})$, and manganese $(\mathrm{Mn})$. These nutrients were selected based on PCA results (Fig. 6). Fullstrength Hoagland solution acted as the control. Different letters next to mean values indicate statistical significance $(\alpha<0.05)$

extract solutions. The highest concentrations of manganese were measured in the $50 \mathrm{~g} / \mathrm{L}$ turkey manure extract solution at $380.3 \pm 65.1 \mu \mathrm{g} / \mathrm{L}$ and the control Hoagland solution at $399.7 \pm 15.9 \mu \mathrm{g} / \mathrm{L}$

\section{Nutrient variation in manure extract solutions and plant responses}

\section{Nitrogen}

Manure extract solutions containing the highest nitrate concentrations, including the control solution and the turkey manure extract $(50 \mathrm{~g} / \mathrm{L})$ solution, resulted in the greatest biomass. Nitrate is the preferential form for nitrogen uptake by plants, and the relationship between nitrate uptake and plant growth in hydroponics has been previously reported (Shinohara et al. 2011). Only turkey and cow manure extract solutions containing $50 \mathrm{~g} / \mathrm{L}$ manure had detectable amounts of nitrate, yet plant yields were not significantly different from the other manure extract solutions, as the mean values that were calculated varied greatly (up to $52.0 \pm 24.5 \mathrm{mg} / \mathrm{L}$ ) (Table 1). Nitrate concentrations in the three different chicken manure extract solutions $(10 \mathrm{~g} / \mathrm{L}, 25 \mathrm{~g} / \mathrm{L}$, and $50 \mathrm{~g} / \mathrm{L}$ manure) were negligible ( $<5.0 \mathrm{ppm})$. In the control solution, calcium nitrate was used as the source, and this explains the higher concentration of $\mathrm{NO}_{3}$ in this solution. As for ammonium, a linear response was observed in yield for plants grown with chicken manure extract solutions, as manure concentrations increased (Table 1). This correlation for ammonium was not present in plants grown with cow manure extract solutions, whereby ammonium concentrations remained stable (standard error $\pm 4 \mathrm{mg} / \mathrm{L}$ ).
Ammonium is toxic to plants at higher concentrations (Britto et al. 2001; Savvas et al. 2006; Sonneveld and Voogt 2009). Plants that are susceptible to ammonium toxicity lack the ability to exclude ammonium through the plasma-membrane influx system and, therefore, accumulate excessive amounts in the cytosol (Goyal and Huffaker 1984). Recent studies on barley grown with a high external ammonium concentration showed a $41 \%$ increase in total root respiration imposed by the plasma membrane on the plant root system and a decline in plant growth (Goyal and Huffaker 1984). This increase in energy expenditure, coupled with a lack of calcium, potassium, and magnesium in the nutrient solution, may have contributed to the apparent toxicity displayed by the lettuce and kale plants in this study. In addition, Hoque et al. (2007) previously observed that when a nutrient solution with a nitrogen concentration of $50 \mathrm{mg} / \mathrm{L}$ is used, a reduction in plant yield is observed when the nitrogen source is ammonium; however, this reduced yield is not observed when the nitrogen source is in the form of nitrate.

Recent studies have set different limits for ammonium concentrations in hydroponics. For the manure extract solutions prepared in this study, nitrogen in the form of ammonium comprised 29-79\% of total $\mathrm{N}$ content, and this could partly explain the lower yield recorded for plants grown in the manure extract solutions when compared to the control. That stated, the presence of ammonium at a low concentration may favor plant growth. It has been demonstrated that a supply of $4.7 \% \mathrm{NH}_{4}-\mathrm{N}$ can stimulate lettuce growth and enhance phosphorus uptake (Savvas et al. 2006), while Adams (1999) recommends an $\mathrm{NH}_{4}-\mathrm{N}$ concentration between 10 and $20 \%$. In most commonly used nutrient solutions for greenhouses, however, $40 \%$ of total nitrogen is in 

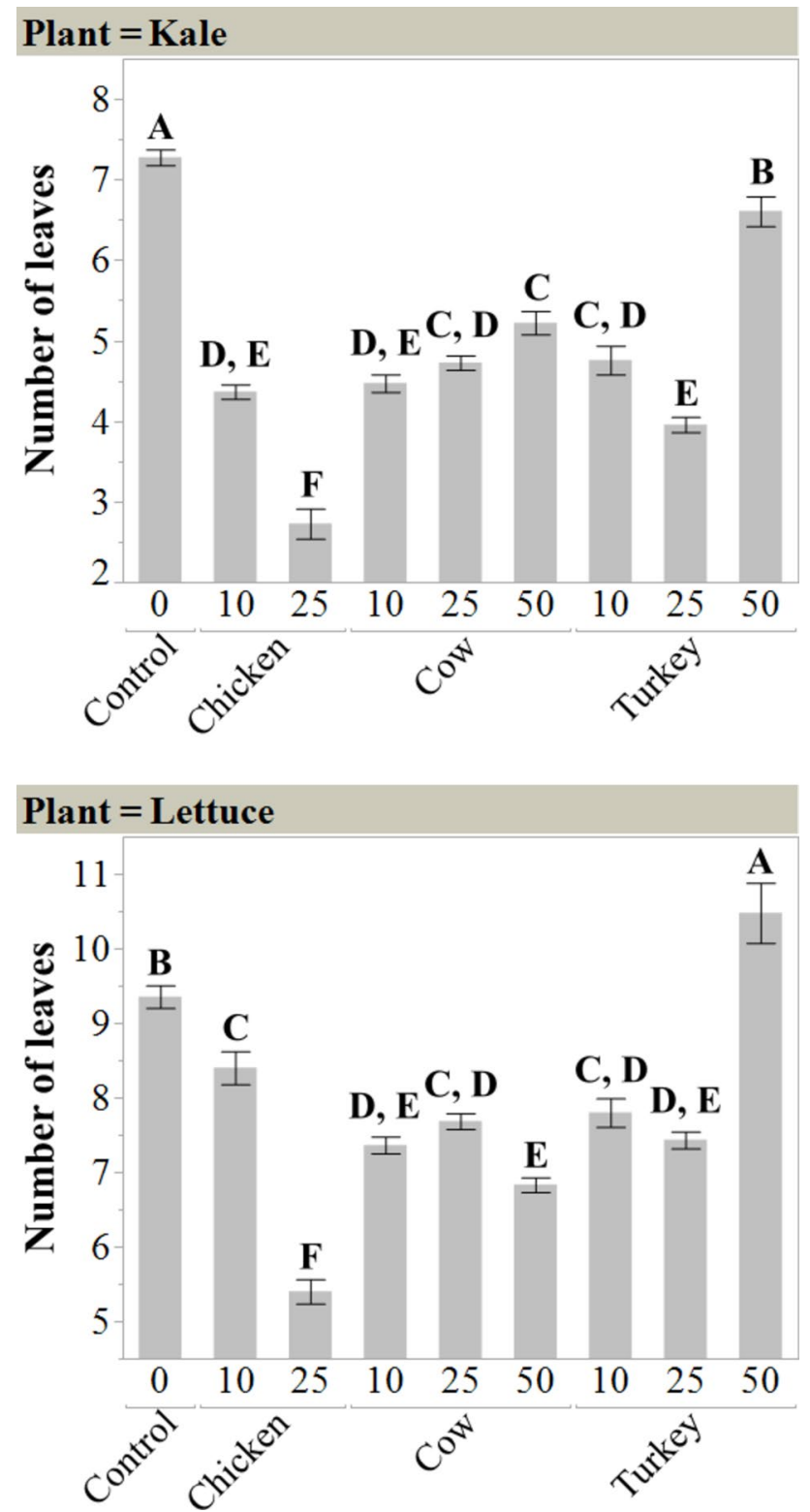

Fig. 4 Mean total number of leaves for kale and lettuce grown in different manure extract solutions ( \pm standard error), using Hoagland solution as the control. Letters above the columns indicate HSD statistical significance $(\alpha<0.05)$

an ammonia-plus-urea form, and this is considered ideal for plant growth (Nelson 2011). It is possible that the high levels of ammonium measured in the turkey manure $(25 \mathrm{~g} / \mathrm{L})$ solution were due to sampling from a fresher point in the manure pile.

The addition of microorganisms can promote ammonification and nitrification in hydroponic systems (Shinohara et al. 2011). When using fish-based fertilizer, for example, the addition of $5 \mathrm{~g} / \mathrm{L}$ bark compost as a source of microorganisms is needed to mineralize organic fertilizer into nitrate (Shinohara et al. 2011). In this study, low manure
Table 2 Target nutrient concentrations in solutions for lettuce (Modified from FAO 2013)

Desired charac- Target concentration in the root environment $(\mathrm{mg} / \mathrm{L})$ teristics

\begin{tabular}{ll}
\hline $\mathrm{EC}$ & $2.60(\mathrm{dS} / \mathrm{m})$ \\
$\mathrm{pH}$ & $5.6-6.5$ \\
$\mathrm{Ca}$ & 292.6 \\
$\mathrm{Mg}$ & 38.9 \\
$\mathrm{NH}_{4}$ & $<10.8$ \\
$\mathrm{NO}_{3}$ & 1116.0 \\
$\mathrm{Mn}$ & 54.9 \\
$\mathrm{Na}$ & $<50 ;$ For sodium, this is the concentration in water \\
& used to prepare the nutrient solution
\end{tabular}

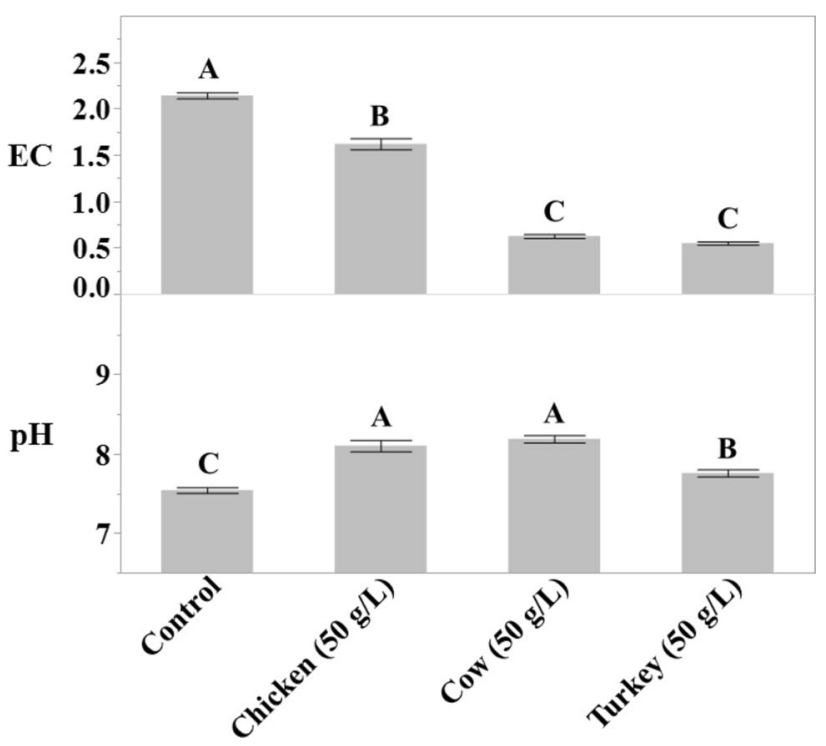

Fig. 5 Mean EC and $\mathrm{pH}$ values for each manure extract solution ( \pm standard error), using Hoagland solution as the control. Letters above the columns indicate HSD statistical significance $(\alpha<0.05)$

concentrations and a lack of additional fertilizer might not have favored the development of nitrifying bacteria. However, pre-composting manure and forced aeration might address this problem. In this study, turkey manure that was exposed to the outside environment for 1-6 months contained a lower concentration of ammonium (between 37.1 and $164.2 \mathrm{mg} / \mathrm{L}$ ) when compared to fresh chicken manure extract solutions (between 100.1 and $366.6 \mathrm{mg} / \mathrm{L}$ ). It is plausible that leaching may have resulted from exposure to the outside environment, which enhanced microbial activity that could have promoted ammonification and nitrification. This might explain the higher nitrate concentration present in turkey manure extract solutions when compared to chicken manure extract solutions (for turkey manure extract solutions, the nitrate concentration ranged between 8.0 and $52.0 \mathrm{mg} / \mathrm{L}$; for chicken, it ranged between 0.5 and $2.7 \mathrm{mg} / \mathrm{L}$ ). 


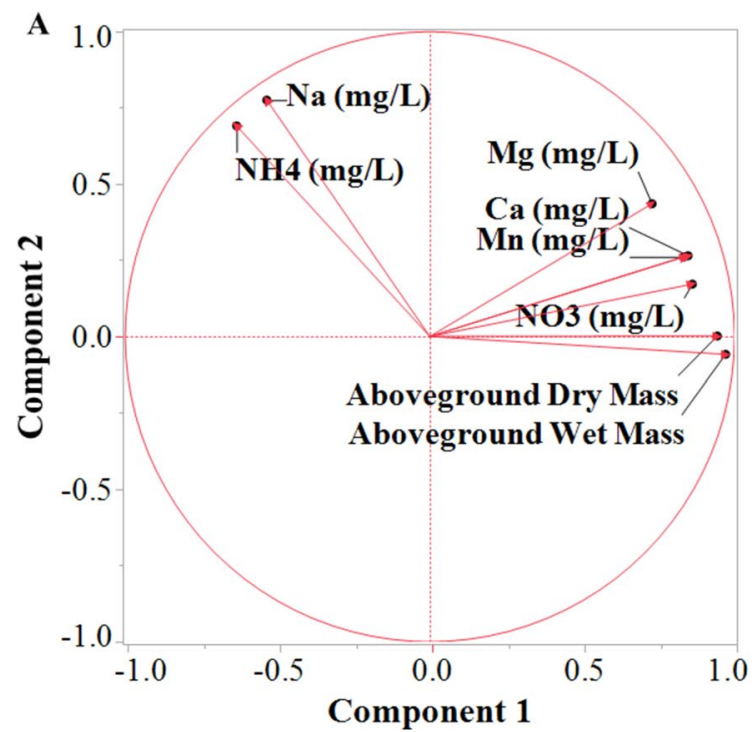

Fig. 6 Principal component analysis of six main nutrients identified for a kale and $\mathbf{b}$ lettuce yield. For both plants, 24 nutrients were originally measured in each manure extract solution. For kale, the first principle component was $65.1 \%$ and it correlated with an increase in aboveground wet and dry mass for $\mathrm{Ca}, \mathrm{Mn}, \mathrm{Mg}$, and $\mathrm{NO}_{3}$. Component 2 was $18.0 \%$ and $\mathrm{Na}$ correlated with an increase in $\mathrm{NH}_{4}$. For

Tiquia and Tam (1998) used forced aeration on pig litter sludge for 80 days, noting a sharp decrease in $\mathrm{NH}_{4}-\mathrm{N}$ and an increase in $\mathrm{NO}_{3}-\mathrm{N}$ and $\mathrm{NO}_{2}-\mathrm{N}$ within the first 20 days of composting (Tiquia and Tam 1998). Cáceres et al. (2006) found comparable results for both $\mathrm{NH}_{4}-\mathrm{N}$ and $\mathrm{NO}_{3}-\mathrm{N}$ in composted cattle manure; however, the experiment lasted 180 days (Cáceres et al. 2006). The addition of fertilizer and forced aeration could improve the population of microorganisms present in the manure extract, enhancing nitrate while decreasing ammonium and creating a more suitable environment for plant growth.

Within the different manure extract solutions, the potassium:nitrogen ratio was always above 4 , even for the control Hoagland solution. Elevated levels of potassium can reduce calcium and manganese uptake, and most vegetative plants require a potassium:nitrogen ratio of 1.2 , while fruitbearing plants can require a higher ratio of 1.5:1 (Adams 1999). For lettuce and tomato plants, ideal potassium: nitrogen ratios are 1.7:1 and 2.5:1, respectively (Adams 1999). For the manure extract solutions analyzed in this study, total dissolved nitrogen was often below $200 \mathrm{mg} / \mathrm{L}$, and it was often present as ammonium. In hydroponically grown plants, the recommended level of nitrogen is approximately $200 \mathrm{mg} / \mathrm{L}$, and for phosphorus, it is approximately $30 \mathrm{mg} / \mathrm{L}$. However, a nitrogen source between 125 and $200 \mathrm{mg} / \mathrm{L}$ and a phosphorus concentration between 10 and $30 \mathrm{mg} / \mathrm{L}$ is acceptable (Adams 1999). It is further recommended that potassium and magnesium concentrations be maintained

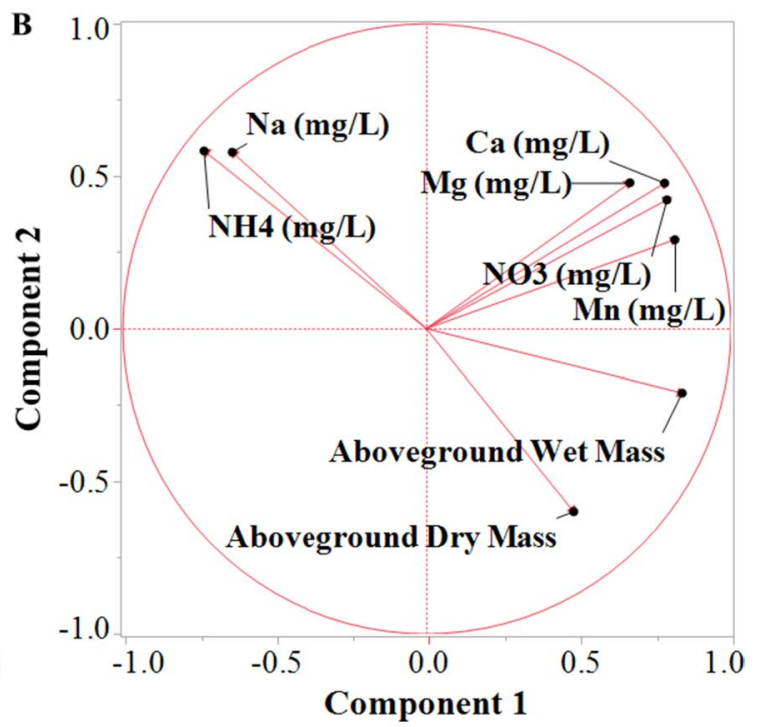

lettuce, the first principal component was 53\% and it correlated with four variables. Component 1 increased with increasing aboveground wet mass for $\mathrm{Ca}, \mathrm{Mn}, \mathrm{Mg}$, and $\mathrm{NO}_{3}$. Component 2 was $22.5 \%$. It increased with only two values, $\mathrm{Na}$ and $\mathrm{NH}_{4}$, and decreased with aboveground dry mass

below 400 and $80 \mathrm{mg} / \mathrm{L}$, respectively, as higher concentrations can prevent calcium uptake (Adams 1999). For the manure extract solutions in this study, potassium concentrations ranged between 27.2 and $228.2 \mathrm{mg} / \mathrm{L}$, while magnesium concentrations were between 3.5 and $29.1 \mathrm{mg} / \mathrm{L}$. Since most nutrients were lower than the ones deemed optimal for plant growth, adjusting the manure extract solutions could minimize plant nutrient deficiency and prevent some plant diseases.

\section{Sodium}

It is currently recommended that salt concentrations be kept below $1,200 \mathrm{mg} / \mathrm{L}$ for optimal plant growth (Cáceres et al. 2006; Nowak and Nowak 1990; Urban and Urban 2010). In this experiment, the highest sodium levels were present in the chicken manure extract $(50 \mathrm{~g} / \mathrm{L})$ solution at $50.2 \mathrm{mg} / \mathrm{L}$, and the sodium concentration peaked at $42.2 \mathrm{mg} / \mathrm{L}$ in the turkey manure extract $(25 \mathrm{~g} / \mathrm{L})$. These data show that the lettuce and kale plants likely did not suffer from salt toxicity.

High salt concentrations can improve sweet pepper and cucumber coloration (Janse 1988, 1989). However, a high salt concentration can also limit yellow colouring and leave russeting for tomatoes while maintaining lettuce leaf firmness (Urban and Urban 2010). In addition, some degree of salinity can increase lettuce yield and turgor, but results vary between cultivars (Bartha et al. 2015). 
Nutrient solution analyses demonstrated that sodium and ammonium concentrations were similar, and increased manure concentrations correlated with increased sodium and ammonium levels (Fig. 6). Based on leaf tissue analysis, it was determined that sodium concentrations decreased in lettuce and kale leaves when sodium concentrations in the manure extract solutions increased (supplementary material; Table 3). For example, the leaf sodium concentration of lettuce grown in cow manure extract $(10 \mathrm{~g} / \mathrm{L}$ and $50 \mathrm{~g} / \mathrm{L})$ solutions decreased from $4.1 \mathrm{mg} / \mathrm{g}$ to $1.3 \mathrm{mg} / \mathrm{g}$ as the manure extract solution increased from 12.5 to $29.6 \mathrm{mg} / \mathrm{L}$. A reduction in leaf salt content may be a salt exclusion strategy (Bartha et al. 2015), while differences in salt tolerance between lettuce cultivars should also be taken into consideration (Bartha et al. 2015).

\section{Calcium}

For all manure extract solutions in this study, calcium content increased with an increase in manure concentration. High salt concentrations, including $\left[\mathrm{Na}^{+}\right],\left[\mathrm{NH}_{4}{ }^{+}\right],\left[\mathrm{K}^{+}\right]$, and $\left[\mathrm{Mg}^{++}\right]$, can induce calcium deficiency in plants (Adams 1999; Meharg and Marschner 2012) and signs of salt toxicity include stunted root and aboveground tissue growth (Bartha et al. 2015). Salt stress may disturb calcium uptake by reducing calcium influx via the plasma membrane and by increasing efflux from plant cells (Bartha et al. 2015). In this study, calcium levels in lettuce tissue were higher when grown in cow manure extract $(10 \mathrm{~g} / \mathrm{L}$ and $25 \mathrm{~g} / \mathrm{L})$ solutions than when grown in the control solution (approximately $14-15 \mathrm{mg} / \mathrm{g}$ dry tissue versus $11 \mathrm{mg} / \mathrm{g}$; supplementary material; Table 3 ). At a high concentration of ammonium in all manure extract solutions, a small decrease in calcium was observed in lettuce leaf tissue, and the lowest calcium concentration was recorded in the turkey manure extract $(25 \mathrm{~g} / \mathrm{L})$ solution. For kale, the calcium content in leaves was always below that of the control solution and a similar trend was observed, where an increase in ammonium in the manure extract solution resulted in decreased calcium content in leaves from plants grown in a higher manure concentration, such as chicken and turkey manure extract solutions containing $25 \mathrm{~g} / \mathrm{L}$ manure.

The recommended level of calcium in hydroponic systems is approximately $50-150 \mathrm{mg} / \mathrm{L}$ (FAO 2013). In this study, the only solution that met this recommendation was the control (Hoagland) solution at $159.0 \mathrm{mg} / \mathrm{L}$. Without adequate calcium levels, plants might experience salt stress and might develop blossom-end rot (Adams 1999). Contrarily, high concentrations of calcium in nutrient solutions appear beneficial to lettuce. In a nutrient solution containing $300 \mathrm{ppm} \mathrm{Ca}{ }^{++}$, leaf and tissue strength increased (Neeser et al. 2007). Therefore, maintaining high calcium concentrations in hydroponic nutrient solutions is preferred.

\section{Magnesium}

The magnesium concentration in all manure extract solutions increased with increasing manure concentrations. Earlier studies have shown that the addition of magnesium fertilizer increases magnesium content in lettuce tissues (Holmes and Crowley 1944). Notably, the amount of magnesium in leaf tissue decreased in kale grown in both chicken and turkey extract solutions, as the manure concentration increased. However, magnesium leaf content increased for kale grown in cow manure solutions, as the manure concentration increased. Furthermore, the magnesium content in lettuce leaves decreased in all solutions, as the manure concentration increased (supplemental material; Table 3). Further experiments should be performed to determine if this fluctuation was caused by species-specific salt tolerance or salt stress, particularly inflicted by $\mathrm{Na}^{+}$and $\mathrm{NH}_{4}{ }^{+}$.

\section{Manganese}

At high concentrations, manganese positively affects lettuce and other vegetable plant yields (Cowan 2006). The highest recorded manganese concentration in this experiment was $0.4 \mathrm{mg} / \mathrm{L}$ and this corresponded to the turkey manure extract $(50 \mathrm{~g} / \mathrm{L})$ solution that also yielded the highest aboveground wet mass. It is important to note that manganese accumulation in kale and lettuce leaves was below any levels that could have caused risk to human health, as suggested levels are estimated at $2.3 \mathrm{mg} / \mathrm{day}$ and $1.8 \mathrm{mg} /$ day for men and women, respectively (Przybysz et al. 2017). Even if the chicken manure extract solution had a higher manganese concentration than the other manure extract solutions, a high concentration of ammonium might have inhibited growth more than Mn would have benefited plant growth. The optimal manganese concentration in a nutrient solution that maximizes lettuce yield is estimated between 0.1 and $0.5 \mathrm{ppm}$ (Vlamis and Williams 1973). Therefore, a decrease in ammonium might allow plants to benefit from the other nutrients present in manure extract solutions.

In this study, all plants grown in the chicken manure extract solution containing $50 \mathrm{~g} / \mathrm{L}\left(50 \mathrm{~kg}\right.$ per $\left.10 \mathrm{~m}^{2}\right)$ manure died before the end of the experiment. The highest plant yield recorded was grown in a extract solution containing $10 \mathrm{~g} / \mathrm{L}$ $\left(10 \mathrm{~kg}\right.$ per $\left.10 \mathrm{~m}^{2}\right)$ manure, and plant yield decreased at a manure concentration of $25 \mathrm{~g} / \mathrm{L}$ ( $25 \mathrm{~kg}$ per $10 \mathrm{~m}^{2}$ ). A study by Engelbrecht et al. (2012) showed a positive yield for cabbage plants when applied with chicken manure at a rate of $12.5 \mathrm{~kg}-25 \mathrm{~kg}$ per $10 \mathrm{~m}^{2}$ (Engelbrecht et al. 2012). Moreover, Muñoz et al. (2004) observed an increase in soil-available phosphorous and fruit yield for papayas when $15 \mathrm{~kg}$ per $10 \mathrm{~m}^{2}$ (15 t per ha) of chicken manure was applied (Muñoz et al. 2004). Fresh chicken manure can be used when preparing nutrient solutions; however, a preliminary manure-composting 
period accompanied by the addition of biomass and forced aeration could improve the composition of the nutrient solution while minimizing the presence of harmful elements. Compost preparation and quality assessments have been extensively reviewed in Bernal et al. (2009).

\section{Other minerals}

The concentrations of three metals, copper, iron, and zinc were present in the manure extract solutions at concentrations that were below those suggested by the FAO (FAO 2013). It might be necessary to increase these metals' concentrations with different fertilizers or additives. Recent studies identified lettuce as a plant that is sensitive to inorganic contaminants, where the half maximal effective concentration $\left(\mathrm{EC}_{50}\right)$ on root elongation was $49 \mu \mathrm{M}$ for copper $(11.4 \mathrm{mg} / \mathrm{L})$ and $260 \mu \mathrm{M}$ for zinc $(17.0 \mathrm{mg} / \mathrm{L})$ (Lamb et al. 2010). As mentioned above, copper and zinc concentrations in the manure extracts did not exceed $0.8 \mathrm{mg} / \mathrm{L}$ and $1.2 \mathrm{mg} / \mathrm{L}$, respectively. Suggested zinc, copper, and iron concentrations for a nutrient solution are $0.13 \mathrm{ppm}$, 0.03 ppm, and 0.94 ppm (Brechner et al. 1996). Iron availability in a nutrient solution promotes zinc uptake while decreasing manganese and cadmium uptake in lettuce (Ys et al. 1991). Therefore, further studies could investigate iron, zinc, and copper uptake in lettuce and kale, using the addition of different nutrients at different concentrations in manure extracts.

\section{Conclusion}

Kale and lettuce growth was attained in all animal manure extract hydroponic solutions, with the exception of chicken manure at $50 \mathrm{~g} / \mathrm{L}$. The highest aboveground biomass achieved was lettuce grown with a turkey manure extract solution $(50 \mathrm{~g} / \mathrm{L})$. All other manure extract solutions resulted in kale yields that were lower than the control Hoagland solution. Based on a PCA analysis, monitoring ammonium, nitrate, potassium, manganese, magnesium, calcium, and sodium levels is critical for preventing nutrient toxicity and deficiency. Monitoring plant growth at higher concentrations of cow and turkey manure may determine an upper limit of manure concentration before reaching toxic levels that inhibit plant growth. The implementation of a pre-processing step, either via composting with additional biomass or forced aeration, could increase nitrate concentrations while reducing ammonium concentrations in manure extracts, consequently preventing ammonium toxicity in chicken and turkey manure extracts.

Open Access This article is distributed under the terms of the Creative Commons Attribution 4.0 International License (http://creativeco mmons.org/licenses/by/4.0/), which permits unrestricted use, distribution, and reproduction in any medium, provided you give appropriate credit to the original author(s) and the source, provide a link to the Creative Commons license, and indicate if changes were made.

\section{References}

AboSedera F, Shafshak NS, Shams A, Abul-Soud M, Mohammed M (2015) The utilize of vermicomposting outputs in substrate culture for producing snap bean. Ann Agric Sci 53:139-151

Abul-Soud MA, Emam MSA, Hawash AMH, Mohammed MH, Maharik ZY (2016) The utilization of vermicompost outputs in ecology soilless culture of lettuce. J Agric Ecol Res Int 5:1-15. https://doi. org/10.9734/JAERI/2016/20008

Adams P (1999) Plant nutrition demystified. Acta Hortic 481:341344. https://doi.org/10.17660/ActaHortic.1999.481.39

Agriculture and Agri-Food Canada (2017) Statistical overview of the Canadian vegetable industry-2016 Government of Canada. http://www.agr.gc.ca/eng/industry-markets-and-trade/canadianagri-food-sector-intelligence/horticulture/horticulture-secto r-reports/statistical-overview-of-the-canadian-vegetable-indus try-2017/?id=1541522324172. Accessed 24 Jan 2019

Arancon NQ, Pant A, Radovich T, Hue NV, Potter JK, Converse CE (2012) Seed germination and seedling growth of tomato and lettuce as affected by vermicompost water extracts (teas). HortScience 47:1722-1728. https://doi.org/10.21273/HORTS CI.47.12.1722

Bartha C, Fodorpataki L, del Carmen Martinez-Ballesta M, Popescu O, Carvajal M (2015) Sodium accumulation contributes to salt stress tolerance in lettuce cultivars. J Appl Bot Food Qual 88:1. https://doi.org/10.5073/JABFQ.2015.088.008

Bernal MP, Alburquerque J, Moral R (2009) Composting of animal manures and chemical criteria for compost maturity assessment. A Rev Bioresour Technol 100:5444-5453. https://doi. org/10.1016/j.biortech.2008.11.027

Brechner M, Both AJ, Staff CE (1996) Hydroponic lettuce handbook. Cornell University, Ithaca, NY, US 504-509

Britto DT, Siddiqi MY, Glass AD, Kronzucker HJ (2001) Futile transmembrane NH4 + cycling: a cellular hypothesis to explain ammonium toxicity in plants. Proc Natl Acad Sci USA 98:42554258. https://doi.org/10.1073/pnas.061034698

Cabrera ML, Beare MH (1993) Alkaline persulfate oxidation for determining total nitrogen in microbial biomass extracts. Soil Sci Soc Am J 57:1007-1012. https://doi.org/10.2136/sssaj 1993.03615995005700040021x

Cáceres R, Flotats X, Marfà O (2006) Changes in the chemical and physicochemical properties of the solid fraction of cattle slurry during composting using different aeration strategies. Waste Manage 26:1081-1091. https://doi.org/10.1016/j.wasma n.2005.06.013

Carballo T, Gil MV, Calvo LF, Moran A (2009) The influence of aeration system, temperature and compost origin on the phytotoxicity of compost tea. Compost Sci Util 17:127-139. https://doi. org/10.1080/1065657X.2009.10702411

Cowan D (2006) Measure and manage-manganese. Agri-Food Laboratories. http://www.agtest.com/articles/manganese.pdf. Accessed 25 Feb 2016

Duffy B, Sarreal C, Ravva S, Stanker L (2004) Effect of molasses on regrowth of E. coli O157:H7 and Salmonella in compost teas. Compost Sci Util 12:93-96. https://doi.org/10.1080/10656 57X.2004.10702163

Ebina J, Tsutsui T, Shirai T (1983) Simultaneous determination of total nitrogen and total phosphorus in water using peroxodisulfate oxidation. Water Res 17:1721-1726. https://doi.org/10.1016/00431354(83)90192-6

El-Shinawy MZ, Abd-Elmoniem EM, Abou-Hadid AF (1999) The use of organic manure for lettuce plants grown under NFT conditions. Acta Hortic. https://doi.org/10.17660/actahortic.1999.491.47

Engelbrecht GM, Ceronio GM, Mbatha AN (2012) Influence of organic fertiliser on yield and quality of cabbage (Brassica oleraceae var 
capitata L.). Acta Hortic. https://doi.org/10.17660/actahortic .2012.936.29

FAO (2013) In: Baudoin W (2013) Good agricultural practices for greenhouse vegetable crops: principles for mediterranean climate areas. FAO plant production and protection paper 2017. http:// www.fao.org/3/a-i3284e.pdf. Accessed 24 Jan 2018

Fritz J, Franke-Whittle I, Haindl S, Insam H, Braun R (2012) Microbiological community analysis of vermicompost tea and its influence on the growth of vegetables and cereals. Can J Microbiol 58:836-847. https://doi.org/10.1139/w2012-061

Garland JL, Alazraki MP, Yorio NC (1999) Composting inedible crop residue for advanced life support systems: nutrient extraction and recycling for hydroponic plant growth. Paper presented at the international composting symposium, Halifax, Canada

Garraway JL (1982) Investigations on the use of treated pig slurry in recirculating water culture of tomatoes. Agric Wastes 4:247265. https://doi.org/10.1016/0141-4607(82)90001-4

Goyal SS, Huffaker RC (1984) Nitrogen toxicity in plants. Nitrogen in crop production $97-118$

Haghighi M, Barzegar MR, da Silva JAT (2016) The effect of municipal solid waste compost, peat, perlite and vermicompost on tomato (Lycopersicum esculentum $L$.) growth and yield in a hydroponic system. Int J Recycl Org Waste Agric 5:231-242. https://doi.org/10.1007/s40093-016-0133-7

Haller H, Jonsson A, Rayo KM, López AD (2016) Microbial transport of aerated compost tea organisms in clay loam and sandy loam-a soil column study. Int Biodeterior Biodegrad 106:10 15. https://doi.org/10.1016/j.ibiod.2015.10.002

Hargreaves JC, Adl MS, Warman PR (2009) Are compost teas an effective nutrient amendment in the cultivation of strawberries? Soil and plant tissue effects. J Sci Food Agric 89:390-397. https ://doi.org/10.1002/jsfa.3456

Hoagland DR, Arnon DI (1950) The water-culture method for growing plants without soil. Circular. California agricultural experiment station, p. 347

Holmes A, Crowley L (1944) Influence of calcium and magnesium upon composition of Boston head lettuce. J Food Sci 9:418-426. https://doi.org/10.1111/j.1365-2621.1944.tb16711.x

Hoque MM, Ajwa HA, Smith R (2007) Nitrite and ammonium toxicity on lettuce grown under hydroponics. Commun Soil Sci Plant Anal 39:207-216. https://doi.org/10.1080/00103620701759194

Ingham ER (2000) Brewing compost tea. Kitchen Gard 29:16-19

Ingham ER (2002) The compost tea brewing manual. Corvallis, USA

Ingham DT, Millner PD (2006) Factors affecting compost tea as a potential source of Escherichia coli and Salmonella on fresh produce. J Food Protect 70:828-834. https://doi. org/10.4315/0362-028x-70.4.828

Jack ALH, Nelson EBN (2010) Suppression of Pythium damping off with compost and vermicompost: Final report to the organic farming research foundation. Greenhouse Growers

Janse J (1988) Cropping measures and the quality of cucumber: positive effect of irradiation on quality (in Dutch). Tuinderij 68:30-32

Janse J (1989) Low EC and ammonium favourable for keeping quality (in Dutch). Groen-ten en Fruitj 44:43

Kumar RR, Cho JY (2014) Reuse of hydroponic waste solution. Environ Sci Pollut Res 21:9569-9577. https://doi.org/10.1007/ s11356-014-3024-3

Lachat Instruments (2008a) QuickChem method 10-107-06-2-C (ammonium) and 10-107-04-1 C (nitrate) WI, USA

Lachat Instruments (2008b) QuickChem method 10-107-04-1-C. Phosphorus WI, USA

Lamb DT, Ming H, Megharaj M, Naidu R (2010) Relative tolerance of a range of Australian native plant species and lettuce to copper, zinc, cadmium, and lead. Arch Environ Contam Toxicol 59:424-432. https://doi.org/10.1007/s00244-010-9481-x
Lee S, Lee J (2015) Beneficial bacteria and fungi in hydroponic systems: types and characteristics of hydroponic food production methods. Sci Hortic 195:206-215. https://doi.org/10.1016/j. scienta.2015.09.011

Leudtke B (2010) Use of compost tea as a nutrient amendment for plant growth in a re-circulating hydroponic system. Disseration, University of Wisconsin-Stevens

Meharg A, Marschner P (2012) Marschner's mineral nutrition of higher plants. Hohenheim, Germany

Muñoz MA, Rafols N, O'Hallorans JM (2004) Yield and yield components of papaya grown on Coto clay (Typic Eutrustox) and fertilized with chicken manure. J Agr U Puerto Rico 88:123-134

Nartey EG, Amoah P, Ofosu-Budu GK, Muspratt A, Sk Pradhan (2017) Effects of co-composting of faecal sludge and agricultural wastes on tomato transplant and growth. Int J Recycl Org Waste Agric 6:23-36. https://doi.org/10.1007/s40093-016-0149-z

Neeser C, Savidov N, Driedger D (2007) Production of hydroponically grown calcium fortified lettuce. Acta Hortic 744:317-322. https ://doi.org/10.17660/ActaHortic.2007.744.33

Nelson PV (2011) Greenhouse operation and management. Prentice Hall, North Carolina

Nowak J, Nowak J (1990) Postharvest handling and storage of cut flowers, florist greens, and potted plants. Portland, OR, USA

On A, Wong F, Ko Q, Tweddell RJ, Antoun H, Avis TJ (2015) Antifungal effects of compost tea microorganisms on tomato pathogens. Biol Control 80:63-69. https://doi.org/10.1016/j.biocontrol .2014.09.017

Otsuki A (1978) A reactivation solution for a copperized cadmium column in the automatic determination of nitrate in natural waters. Anal Chim Acta 99:375-377. https://doi.org/10.1016/S0003 -2670(01)83582-0

Pane C, Palese AM, Spaccini R, Piccolo A, Celano G, Zaccardelli M (2016) Enhancing sustainability of a processing tomato cultivation system by using bioactive compost teas. Sci Hort 202:117-124. https://doi.org/10.1016/j.scienta.2016.02.034

Przybysz A, Wrochna M, Gawrońska H, Małecka-Przybysz M, Pietrzyk S, Gawroński SW (2017) Effect of manganese on yield and quality of hydroponically grown lettuce. J Elem 22:315-327. https://doi. org/10.5601/jelem.2016.21.1.1127

Radin AM, Warman PR (2011) Effect of municipal solid waste compost and compost tea as fertility amendments on growth and tissue element concentration in container grown tomato. Commun Soil Sci Plant Anal 42:1349-1362. https://doi.org/10.1080/00103 624.2011.571742

Savvas D, Passam H, Olympios C, Nasi E, Moustaka E, Mantzos N, Barouchas P (2006) Effects of ammonium nitrogen on lettuce grown on pumice in a closed hydroponic system. HortScience 41:1667-1673. https://doi.org/10.21273/HORTSCI.41.7.1667

Scheuerell S, Mahaffee W (2002) Compost tea: principles and prospects for plant disease control. Compost Sci Util 10:313-338. https://doi.org/10.1080/1065657X.2002.10702095

Shinohara M, Aoyama C, Fujiwara K, Watanabe A, Ohmori H, Uehara Y, Takano M (2011) Microbial mineralization of organic nitrogen into nitrate to allow the use of organic fertilizer in hydroponics. J Soil Sci Plant Nutr 57:190-203. https://doi.org/10.1080/00380 768.2011.554223

Sonneveld C, Voogt W (2009) Nutrient solutions for soilless cultures. Plant Nutrition of Greenhouse Crops. https://doi. org/10.1007/978-90-481-2532-6_12

Surendran U, Chandran C, Joseph EJ (2016) Hydroponic cultivation of Mentha spicata and comparison of biochemical and antioxidant activities with soil-grown plants. Acta Physiol Plant 39:26. https ://doi.org/10.1007/s11738-016-2320-6

Suvo T, Ahamed M, Haque M, Chakrobarti M, Biswas H (2017) Identification of suitable media based on hydroponic culture for 
production Zucchini squash. Int J Agric Res Innov Technol. https ://doi.org/10.3329/ijarit.v6i2.31695

Tiquia SM, Tam NFY (1998) Elimination of phytotoxicity during cocomposting of spent pig-manure sawdust litter and pig sludge. Bioresour Technol 65:43-49. https://doi.org/10.1016/S0960 -8524(98)00024-8

Tomasi N, Pinton R, Dalla Costa L, Cortella G, Terzano R, Mimmo T, Scampicchio M, Cesco S (2015) New 'solutions' for floating cultivation system of ready-to-eat salad: a review. Trends Food Sci Technol 46:267-276. https://doi.org/10.1016/j.tifs.2015.08.004

Urban L, Urban I (2010) La production sous serre, tome 1: la gestion du climat, tome 2: L'irrigation fertilisante en culture hors sol. France

Vlamis J, Williams DE (1973) Manganese toxicity and marginal chlorosis of lettuce. Plant Soil 39:245-251. https://doi.org/10.1007/ bf00014791

Welke SE (2005) The effect of compost extract on the yield of strawberries and the severity of Botrytis cinerea. J Sustain Agric 25:57-68. https://doi.org/10.1300/J064v25n01_06

Williams KA, Nelson JS (2014) Challenges of using organic fertilizers in hydroponic production systems. In: International horticultural congress on horticulture, pp 365-370
Ys C, Vanthomme P, Schrevens E, Proft Md (1991) Interactions of $\mathrm{Cd}$ with $\mathrm{Zn}, \mathrm{Cu}, \mathrm{Mn}$ and $\mathrm{Fe}$ for lettuce (Lactuca sativa L.) in hydroponic culture. Plant Cell Environ 14:713-717. https://doi. org/10.1111/j.1365-3040.1991.tb01545.x

Zarcinas BA, Cartwright B, Spouncer LR (1987) Nitric acid digestion and multi-element analysis of plant material by inductively coupled plasma spectrometry. Commun Soil Sci Plant Anal 18:131146. https://doi.org/10.1080/00103628709367806

Zhai Z (2009) Organic fertilizers for greenhouse tomatoes: productivity and substrate microbiology. HortScience 44:800-809

Publisher's Note Springer Nature remains neutral with regard to jurisdictional claims in published maps and institutional affiliations. 